\title{
Melanocortin 4 receptor $(M c 4 r)$ gene polymorphism and its association with body weights of some breeds of rabbit
}

Osaiyuwu, O. H., Bolaji, U. F. O., Adeyinka, O. A., Akinyemi, M. O. and Salako, A. E. Animal Breeding and Genetics Unit, Department of Animal Science,

University of Ibadan, Nigeria.

Corresponding author: cosamede@yahoo.com

Abstract

In livestock production, traditional methods of selection have always been the way to go. However, with the advent of genomics techniques, methods such as PCR-RFLP is been employed to identify single nucleotide polymorphism of likely candidate genes useful for livestock selection and improvement. Therefore, the aim of this study was to investigate the association of Melanocortin 4 Receptor (MC4R) gene polymorphism with the body weight of rabbits. Seventy-four rabbits were used for this study consisting of six breeds; 6 Chinchilla, 3 Californian, 11 Dutch, 4 English Spot, 10 New Zealand White and 20 Fauve de Bourgogne (FDB) breeds. Blood samples were collected from the animals with needle and syringe and transferred unto FTA cards and stored away from light. Body weight measurements on the animals were recorded from 2 weeks to 20 weeks. PCR-RFLP analysis produced three genotypes $A A, A G, G G$ with genotype frequency of $0.14,0.69$ and 0.18 respectively. Allele frequency 0.48 and 0.52 for allele $A$ and $G$ respectively was obtained. Chi-square test showed that the population was not in Hardy-Weinberg equilibrium. Association analysis between the MC4R "c.101G>A" SNP and body weight of rabbit was tested using GLM procedure of $S A S$ programme. Genotype GG had higher body weight $(p<0.05)$ at 12, 16 and 20 weeks in the Dutch rabbits while genotype AA recorded a higher $(p<0.05)$ body weight value at 12 weeks in New Zealand White rabbits. More so, female Dutch rabbits had higher $(p<0.05)$ mean weight than the males at 12,16 and 20 weeks of age. Male New Zealand White breeds recorded higher $(p<0.05)$ mean weight than the female animals. The result of the study showed that MC4R "c.101G>A" SNP was not associated with the body weight in the studied rabbit population, although, genotype AA had higher mean weight values at 12, 16 and 20 weeks of age than genotypes $A G$ and $G G$.

Keywords: DNA Analysis, FTA Cards, Genetic Variation, PCR-RFLP, Single Nucleotide Polymorphism

\section{Introduction}

Rabbit as a micro-livestock possesses some important attributes such as small body size, short generation interval, ability to utilize less competitive feeds, rapid growth, potentials for genetic improvement and production of high-quality meat and useful by-products (Cheeke 1986; Egbo et al., 2001; Herbert, 2011). Apart from high temperature usually above $30^{\circ} \mathrm{C}$ which may impose undue stress on the animal, rabbit production can significantly contribute to man's need for alternative protein source at all times. Genetic improvement of rabbit is important in order to increase their contribution to the much-needed animal protein (Hristova et al., 2018). Research in molecular biology has led to the development of techniques and knowledge that assist and complement the traditional system of genetic improvement (Pereira et al., 2005). The direct application of molecular techniques of a candidate gene approach can represent a quite effective approach to identify DNA markers associated with production traits in livestock (Rothschild and Soller, 1997). 


\section{Melanocortin Receptor Gene Polymorphism}

Researchers have investigated candidate genes for reproduction (Peiro' et al., 2008), meat deposition and growth traits in rabbits (Fontanesi et al., 2011).

Melanocortin is a protein in animals encoded by the Melanocortin 4 Receptor (MC4R) gene (Magenis et al 1994; Sundaramurthy et al., 1998). The gene encodes $M C 4$ protein, a G protein-coupled receptor that binds Alpha-melanocytes stimulating hormone. In murine models, MC4 receptors have been found to be involved in feeding behaviour, regulation of metabolism, sexual behaviour and male erectile function (Fan et al., 1997). The central melanocortinergic pathway plays an important role in the control of mammalian energy homeostasis, and has recently been highlighted by genetic studies in obese humans and mice by Huszar et al., (1997). Single-nucleotide polymorphism (SNP) is a potent method for detecting polymorphisms caused by point mutations that give rise to different alleles containing alternative bases at a given nucleotide position within locus (Liu et al., 2014). Therefore, the present study was carried out to evaluate the association between (MC4R) gene polymorphism and live body weight of rabbits.

\section{Materials and methods}

A heterozygous population of rabbits were used for this study at a farm situated in Ibadan, Nigeria (70 25' 48" North and 30 56' 20" East). Seventy-four (74) rabbits consisting of six different breeds (20 Fauve de Bourgogne, 26 Chinchilla, 10 New
Zealand white, 11 Dutch, 4 English Spot and 3 Californian) were used for this study. Commercial diet and clean drinking water were provided ad-libitum to the rabbits. Diet requirement was according to Ouyed and Brun (2008) for micro livestock (2375 $\mathrm{kcal} / \mathrm{kg}$ metabolisable energy and 16.4\% crude protein, $13.3 \%$ crude fibre). Animals were also placed on forages to aid digestion and prevent gastrointestinal stasis. Body weight of rabbits were measured weekly from 2 weeks until 20 weeks. Blood samples $(3 \mathrm{ml})$ were obtained from the jugular vein of rabbits with needle and syringe and transferred onto FTA cards, which were stored at room temperature away from light until use.

\section{DNA extraction}

Genomic DNA was extracted from the FTA cards as described: $1 \mathrm{~mm}$ disks were put in eppendorf tubes, and $150 \mu \mathrm{l}$ of $100 \mathrm{Mm}$ Tris SDS was added; the tubes were rotated up and down for $30 \mathrm{~min}$, spent solution from the tube was discarded; $150 \mu 1$ of water was then added and rotated for 10 mins. Spent solution was again discarded; washing was repeated without rotation but left to rest for10 mins. Spent solution was then discarded; $30 \mu \mathrm{l}$ of $\mathrm{ddH}_{2} \mathrm{O}$ was again added with the disks submerged; the solution was heated at $90^{\circ} \mathrm{C}$ for $15 \mathrm{~min}$, vortexed and briefly centrifuged, then left for PCR analysis.

\section{PCR amplification and genotyping}

The PCR for rabbit DNA was carried out using primers for $M C 4 R$ gene (127 bp - 5'flanking region) according to Fontanesi et al., (2013) as shown below.

Table 1: PCR primer (Forward and Reverse Sequence) for melanocortin 4 receptor gene

\begin{tabular}{lllll}
\hline $\begin{array}{l}\text { Primer } \\
\text { Name }\end{array}$ & DNA Sequence 5' $-3^{\prime}$ & $\begin{array}{l}\text { Product } \\
\text { size }(\mathrm{bp})\end{array}$ & $\begin{array}{l}\text { Annealing } \\
\text { temperature } \\
\left({ }^{\circ} \mathrm{C}\right)\end{array}$ & $\mathrm{MgCl}_{2}$ \\
\hline MC4R & Forward 5'-CAT GAA CTC CAC CCA CCA C & 127 & 59 & 3.0 \\
& $\begin{array}{l}\text { Reverse 5'-CTC ATA GCA CCC TCC ATC AGA } \\
\text { CTA G -3' }\end{array}$ & & \\
\hline
\end{tabular}

Source: Fontanesi et al. (2013) 


\section{Osaiyuwu, Bolaji, Adeyinka and Salako}

The total PCR reaction volume was $6.25 \mu 1$, including $0.50 \mu \mathrm{l}$ of genomic DNA, $0.50 \mu \mathrm{l}$ of primer mix (Forward and Reverse), 1.25 $\mu 1$ of Surf PCR master Mix, and $4.00 \mu 1$ of Molecular grade $\mathrm{H}_{2} \mathrm{O}$. The PCR was performed using a MiniOne ${ }^{\circledR}$ PCR system in three main steps: Initial denaturation at $96^{\circ} \mathrm{C}$ for $15 \mathrm{~min}$, followed by 35 cycles, denaturation at $94^{\circ} \mathrm{C}$ for $1 \mathrm{~min}$; annealing at $59^{\circ} \mathrm{C}$ for $1 \mathrm{~min}$, extended for $30 \mathrm{~s}$ at $70^{\circ} \mathrm{C}$ then a final extension at $70^{\circ} \mathrm{C}$ for $6 \mathrm{~min}$. Few samples from the Amplicones were ran through electrophoresis to check the quality of Amplicones with 2\% agarose gel and left to run for 20mins to observe band movements. Genotyping of the "c.101G>A" single nucleotide polymorphism (SNP) was carried out by PCR-RFLP using a modified reverse primer that inserts an artificial restriction site for SpeI, when allele A is present in the $127 \mathrm{bp}$ amplified DNA fragment. Briefly, 3 $\mu 1$ of PCR product was digested using 0.25 $\mu 1$ of SpeI (Fermentas, Vilnius, Lithuania), 1 $\mu 1$ of $10 \times$ universal buffer (UB) and $5.5 \mu 1$ of molecular grade $\mathrm{H}_{2} \mathrm{O}$ in a total of $9.75 \mu \mathrm{l}$ of reaction volume. Incubation at $37^{\circ} \mathrm{C}$ for $10 \mathrm{~min}$ and reaction was inactivated at $65^{\circ} \mathrm{C}$ for $20 \mathrm{~min}$. Resulting DNA fragments were electrophoresed with MiniOne ${ }^{\circledR}$ Electrophoresis System in 2\% agarose gels. DNA bands were visualized with $11 \times$ SYBR DNA stain (Jena Biosciences, CA, and USA). PCR-RFLP patterns were the following: allele A resulted in two fragments of 100bp, $27 \mathrm{bp}$; allele $\mathrm{G}$ resulted in an undigested fragment of $127 \mathrm{bp}$.

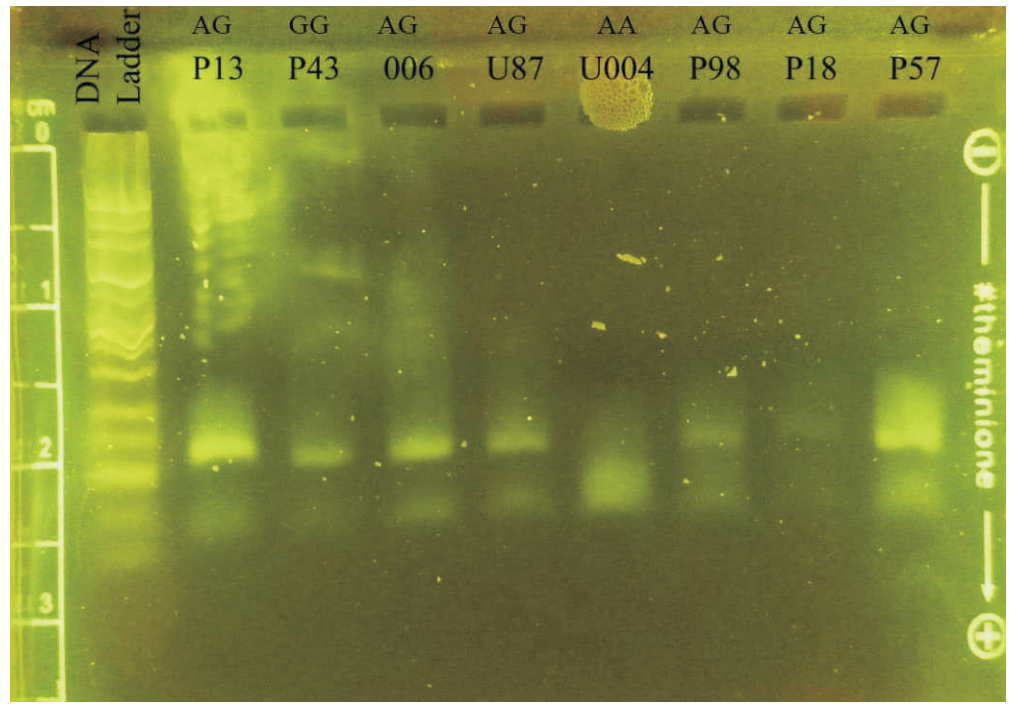

Figure 1: SpeI digestion of PCR product followed by agarose gel electrophoresis. Allele A produced 100-bp fragment, and allele G produced 127-bp fragment

\section{Statistical analysis}

The effects of $M C 4 R$ genotypes on different breeds of rabbit and Association analysis between Body weight and Melanocortin 4 Receptor gene was estimated using the SAS version 9.2. While the deviation of the population from Hardy-Weinberg equilibrium was tested using Population Genetic Analysis (POPGENE 1.32) programe.

\section{Results and discussion}

The "c.101G $>A$ " single nucleotide polymorphism (SNP) was amplified using 


\section{Melanocortin Receptor Gene Polymorphism}

genomic DNA samples. The restriction digest analysis of the PCR product using Spe1 produced the following; allele A produced one fragment of a $100 \mathrm{bp}$ while allele $\mathrm{G}$ produced an undigested fragment of $127 \mathrm{bp}$ while the heterozygote (AG) produced two fragments of $100 \mathrm{bp}$ and 27bp. The PCR-RFLP analysis resulted in three genotypes; two homozygotes (AA and $\mathrm{GG}$ ) and one heterozygote (AG). The analysis of the $M C 4 R$ gene revealed that the population deviated from Hardy Weinberg's Equilibrium as evident in the high chi-square value of 10.3. The frequency for these genotypes were 0.14 for AA, 0.69 for AG and 0.18 for GG, while the allelic frequency for allele $A$ and $G$ were 0.48 and 0.52 , respectively (Table 2 ).

Table 2: Genotype and allele frequencies of the population $w$ ith number of observations in parenthesis

\begin{tabular}{|c|c|c|c|c|c|c|c|c|}
\hline \multicolumn{3}{|c|}{ Genotype Frequency (n) } & \multicolumn{2}{|c|}{ Allele Frequency } & $\mathrm{X}^{2}$ & $\mathrm{G}^{2}$ & $\mathbf{n}_{\mathrm{e}}$ & Nei \\
\hline & $\mathrm{AG}$ & GG & A & G & 10.3 & 10.6 & 2.0 & 0.50 \\
\hline $0.14(10)$ & $0.69(51)$ & $0.18(13)$ & 0.48 & 0.52 & & & & \\
\hline
\end{tabular}

$\mathrm{n}$ : number of observations, $\mathbf{X}^{2}$ : Chi-Square test of Hardy Weinberg's Equilibrum, $\mathbf{G}^{2}$ : Likelihood ratio test for Hardy Weinberg's Equilibrum, ne: Effective number of Alleles, Nei: Nei's Expected Heterozygosity

The Genotypic $(0.14,0.69$ and 0.18 for AA, AG and GG, respectively) and Allelic (A0.48 and G- 0.52) frequencies in the population studied were different from those reported by Fontanesi et al., (2013) and Nahacky et al., (2018) who reported genotypic frequencies of 0.38 for AA, 0.48 for $A G$ and 0.14 for $G G$; and allelic frequencies of 0.63 for A allele and 0.37 for $\mathrm{G}$ allele. The deviation from the HardyWeinberg equilibrium in the population studied may be attributed to limited sample sizes, artificial selection, and the random mating system of different rabbit breeds in a bit to increase performance. The predominant allele was $\mathrm{G}$ in the population studied.

\section{Effect of the MC4R genotypes on the body weight of rabbit}

There was no difference $(p>0.05)$ among the $M C 4 R$ genotypes observed in the rabbit population studied. However, genotype AG had a higher mean value at 8 weeks, while genotype AA had higher mean values at 12 , 16 and 20 weeks of age. Conversely, genotype GG was observed to have lowest mean weight values at all ages (Table 3 ). A level of association was reported for the
"c.101G $>A$ " single nucleotide polymorphism (SNP) in MC4R gene and high body weight in rabbits (Fontanesi et al., 2013; Nahacky et al., 2018). El-Sabrout and Soliman (2017) and El-Sabrout and Aggag (2017) reported association between MC4R SNPs and high body weight of rabbits at 63 days of age. There was however no association $(p>0.05)$ between the "c.101G>A" SNP and the body weight in the studied population. This may be due to the small sample size and the degree of breeds' admixture. Genotype AA seemed to have been more associated with high body weight at 12, 16, and 20 weeks of age than other genotypes. This agreed with what Nahacky et al., (2018) reported in a different line of rabbit. The "c.101G $>$ A" SNP was not associated with the body weight of rabbit in this study.

Effect of genotype on the body weight of rabbits at $8,12,16$ and 20 weeks of age

Differences were observed among the genotypes of New Zealand White breed at 12 weeks with genotype AA having a higher mean weight value $(p<0.05)$. Genotype AA also had higher mean weight values at 8,16 , and 20 weeks of age 


\section{Osaiyuwu, Bolaji, Adeyinka and Salako}

Table 3: Association between MC4R genotypes and body weight (g) in selected rabbit breed

\begin{tabular}{lllll}
\hline \multirow{2}{*}{ Age, weeks } & \multicolumn{3}{l}{ Polymorphic Variants } & \multirow{2}{*}{$p$} \\
\cline { 2 - 4 } & AA $(10)$ & AG $(51)$ & GG $(13)$ & 0.61 \\
\hline 8 & $661 \pm 49.8$ & $663 \pm 22.5$ & $616 \pm 32$ & 0.75 \\
12 & $1078 \pm 82.2$ & $1060 \pm 32.2$ & $1013 \pm 45.9$ & 0.58 \\
16 & $1417 \pm 109$ & $1372 \pm 37$ & $1305 \pm 49.3$ & 0.98 \\
20 & $1583 \pm 130$ & $1568 \pm 42.9$ & $1556 \pm 72.8$ & \\
\hline
\end{tabular}

${ }^{a b c}$ Means in the same row without common letter are different at $p<0.05$

compared to genotypes AG and GG (Table 4). Differences were also observed between genotypes in Dutch rabbits at 12, 16 and 20 weeks respectively (Table 5). Genotype GG had mean values of 130, 169, and 199 at 12,16 and 20 weeks, respectively. Nahacky et al. (2018) reported that genotype AA showed higher values of body weight compared to $\mathrm{AG}$ and $\mathrm{GG}$ genotypes. In addition, Fontanesi et al., (2013) concluded that genotype AA was associated with higher body weight values in the breed of rabbit studied. A similar result was obtained in New Zealand White breeds used in this study, where genotype AA had a higher body weight values $(p<0.05)$ compared to AG and GG genotypes. The Dutch breed also showed differences among the genotypes at 12, 16 and 20 weeks of age with genotype GG having higher body weight $(p<0.05)$ than AA and AG genotypes. This might be due to the small sample size of animals in this category. There was no difference among genotypes $(p>0.05)$ in Fauve de Bourgogne (FDB) and Chinchilla rabbits in the current study. Howevwe genotype AA had higher body weight values for all ages. While Californian and English Spot breeds genotypes could not be compared due to absence of all genotypes in these breeds.

Table 4: Association of MC4R genotypes with body weight (g) in $\mathrm{N}$ ew Zealand white rabbits at $8,12,16$ and 20 weeks of age

\begin{tabular}{lllll}
\hline \multirow{2}{*}{ Age, weeks } & \multicolumn{2}{l}{ Polymorphic Variants } & \\
\cline { 2 - 5 } & AA $(2)$ & AG $(5)$ & GG $(3)$ & 0.19 \\
\hline 8 & $871 \pm 46.1$ & $686 \pm 71.7$ & $602 \pm 79.2$ & $<0.05$ \\
12 & $1440 \pm 14.2^{\mathrm{a}}$ & $1218 \pm 93.7^{\mathrm{ab}}$ & $958 \pm 31.6^{\mathrm{b}}$ & 0.06 \\
16 & $1692 \pm 169$ & $1583 \pm 73.1$ & $1310 \pm 39.7$ & 0.15 \\
20 & $2005 \pm 260$ & $1875 \pm 75.5$ & $1625 \pm 58$ &
\end{tabular}

Table 5: Association of MC4R Genotypes with Body Weight (g) in Dutch Rabbit Breeds at 8, 12, 16 and 20 weeks of Age

\begin{tabular}{ccccc}
\hline \multirow{2}{*}{ Age, weeks } & \multicolumn{3}{c}{ Polymorphic Variants } & \multirow{2}{*}{$p$} \\
\cline { 2 - 4 } & $\mathbf{A A}(\mathbf{1})$ & AG (9) & GG (1) & 0.39 \\
\hline 8 & 533 & $667 \pm 30.6$ & 679 & 0.01 \\
12 & $717^{\mathrm{b}}$ & $1145 \pm 38.4^{\mathrm{a}}$ & $1298^{\mathrm{a}}$ & 0.001 \\
16 & $856^{\mathrm{b}}$ & $1525 \pm 37.2^{\mathrm{a}}$ & $1686.80^{\mathrm{a}}$ & 0.002 \\
\hline 20 & $797^{\mathrm{b}}$ & $1717 \pm 58.3^{\mathrm{a}}$ & $1992.97^{\mathrm{a}}$ &
\end{tabular}

\section{Conclusion}

Although the studied gene locus was polymorphic in the rabbit populations considered in this study, there were no 
association between the "c.101G $>$ A" SNP and body weight $(p>0.05)$ of the selected breeds of rabbit. However, genotype AA may have potentials to be associated with higher body weight values than genotypes AG and GG. Rabbits had different degrees of association of genotypes with body weight $(p>0.05)$ at 12,16 and 20 weeks of age in the Dutch and at 12 weeks of age in New Zealand White. This means that there may be potential for selection on the basis of genotype at the Melanocortin 4 receptor gene locus. It is however recommended that further researches be carried out with larger sample size and more sensitive genotyping approaches such as Next Generation Sequencing (NGS) and other high throughput genotyping methods to further investigate the association between $M C 4 R$ SNPs and body weight of rabbits.

\section{References}

Cheeke, P. R. 1986. Potentials of rabbit production in tropical and subtropical agricultural systems. Journal of Animal Science, 63 (5): $\begin{array}{lllllllll}1 & 5 & 8 & 1 & - & 1 & 5 & 8 & 6\end{array}$, https://doi.org/10.2527/jas1986.6 $\underline{351581 \mathrm{x}}$

Egbo, M. L., Doma, U. D. and Lacdacks, A. B. 2001. Characteristics of small scale rabbit production and management in Bauchi. In: Proceedings of 20th Annual Conference of Nigerian Society of Animal Production, March 18-21, Ahmadu Bello University, Zaria, Nigeria. 160-162.

El-Sabrout, K. and Soliman, F. 2017. Association of Single-nucleotide polymorphism of melanocortin gene with feed intake in rabbit (Oryctolagus cuniculus). Journal of Animal Physiology and Animal Nutrition. Volume 102, Article
\#564-567 from

El-Sabrout, K. and Aggag, S. A. 2017. Association between single nucleotide polymorphism in multiple candidate genes and body weight in rabbits. Veterinary World Journal, Volume 10 (1): 136-139 doi: 10.14202/vetworld.2017.136139

Fan, W., Boston, B. A., Kesterson, R. A., Hruby, V. J. and Cone, R. D. 1997. Role of Melanocortinergic nuerons in feeding and the Agouti obersity Syndrome. Nature, 385 (6612): 165-168.

Fontanesi, L., Scotti E., Cisarova, K., Di Battista, P., Dall'Olio, S., Fonasini, D., and Frabetti, A. 2013. A missense mutation in the rabbit melanocortin 4 receptor $(M C 4 R)$ gene is associated with finishing weight in a meat rabbit line. Animal Biotechnology, Volume 24: 268-277 doi: 10.1080/10495398.2013.781034.

Fontanesi, L., Scotti, E., Frabetti, A., Fornasini, D., Piccone, A. and Russo, V. 2011. Identification of polymorphisms in the rabbit (Oryctolagus cuniculus) myostatin (MSTN) gene and association analysis with finishing weight in a commercial rabbit population. Animal Genetics, Volume 42 Article \#339 doi: 10.1111/j.13652052.2010.02163.x.

Herbert, U. 2011. Unending seeds and waters of animal life. 12th Inaugural lecture series of Michael Okpara University of Agriculture, Umudike, Nigeria, November 2011, Volume 9, Pages 1-41.

Huszar, D., Lynch, C.A., FairchildHuntress, V., Dunmore, J. H., Fang, Q., Berkemeier, L. R., Gu, W., Kesterson, R. A., Boston, B. 


\section{Osaiyuwu, Bolaji, Adeyinka and Salako}

A., Cone, R. D., Smith, F. J. Campfield, L. A. Burn, P. and Lee, F. 1997. Targeted disruption of the melanocortin-4 receptor results in obesity in mice. Cell Volume 88 (1): 131-41. PubMed PMID: 9019399.

Hristova, D., Tanchev, S., Velikov, K., Gonchev, P. and Georgieva, S. 2018. Single nucleotide polymorphism of the growth hormone $(\mathrm{GH})$ encoding gene in inbred and outbred domestic rabbits. World Rabbit Science, Volume 26 (1): 49-55.

Liu, W. C., Chen, S. Y., Jia, X. B., Wang, J. and Lai, S. J. 2014. Effects of variants in proopiomelanocortin and neuropeptide $\mathrm{Y}$ genes on growth, carcass, and meat quality traits in rabbits. AsianAustralasian Journal of Animal Sciences, 2014, Volume 27 ( 5 ) : $6009-615 . \mathrm{D}$ o $\mathrm{i}$ : https://doi.org/10.5713/ajas.2013. 13807

Magenis, R. E., Smith, L., Nadeau, J. H., Johnson, K. R., Mountjoy, K. G. and Cone, R. D. 1994. Mapping of the $\mathrm{ACH}, \mathrm{MSH}$ and Neural (MC3 and MC4) Melanocortin receptor in Mouse and Human. Mammalian Genome, Volume 5 (8): 503-508.

Nahacky, J., Zidek, R., Gabor, M., Miluchova, M., Bucko, O. and Kovacik, A. 2018. $M C 4 R$ and PGAM2 genes polymorphism Association with production traits in Rabbit (Oryctolagus cuniculus). Journal of Microbiology, Biotechnology and Food science, Volume 7 (5): 493-495. doi: 10.15414/jmbfs.2018.7.5.493-495

Ouyed, A. and Brun, J. M. 2008. Comparison of growth performances and carcass qualities of crossbred rabbits from four sire lines in Quebec. 9th World Rabbit Congress Verona-Italy, Pages 189194.

Peiro, R., Merchan, M., Santacreu, M.A., Argente, M. J., Garcia, M. L., Folch, J. M. and Blasco, A. 2008. Identification of single-nucleotide polymorphism in the progesterone receptor gene and its association with reproductive traits in rabbits. Animal Genetics, Volume 180: $\begin{array}{lllllllll}1 & 6 & 9 & 9 & - & 1 & 7 & 0 & 5\end{array}$ doi10.1534/genetics.108.090779.

Pereira, A. P., Alencar, M. M., Oliveira, H. N and Regitano, L. C. A. 2005. Association of $\mathrm{GH}$ and IGF-1 polymorphism with growth traits in synthetic beef cattle breed. Genetics and Molecular Biology, Volum e 28: $670-676$ http://www.scielo.br/pdf/gmb/v28 n2/a09v28n2.pdf

Rothschild, M. and Soller, M. 1997. Candidate gene analysis to detect gene controlling traits of economic importance in domestic livestock. Probe 8: 13-20.

Sundaramurthy, D., Campbell, D. A., Leek, J. P., Markham, A. F. and Pieri, L. F. 1998. Assignment of Melanocortin 4 receptor $(M C 4 R)$ gene to Human chromosome band $18 \mathrm{q} 22$ by in situ hybridization and radiation hybrid mapping. Cytogenetics and Cell Genetics, Volume 82 (1-2): 97-98. https://doi.org/10.1159/000015074

Received: $27^{\text {th }}$ August, 2019

Accepted: $9^{\text {th }}$ December, 2019 